\title{
PENINGKATAN KEMAMPUAN MEMECAHKAN MASALAH MATEMATIK SISWA SMP DENGAN PENDEKATAN KONTEKSTUAL
}

\author{
Elma Lusiana Arafani ${ }^{1}$, Elin Herlina ${ }^{2}$, Luvy Sylviana Zanthy ${ }^{3}$ \\ 1,2,3 IKIP SILIWANGI, Jl. Terusan Jendral Sudirman, Cimahi tengah, Kota Cimahi, Jawa Barat \\ 202015067@student.uksw.edu
}

\begin{abstract}
This study discusses to improve overcoming mathematical problems through contextual learning. The research design used was the design of two groups with the pretest-posttest. The study population was all public junior high school students in the city of Cianjur. The research sample was class VII students of the State Middle School in the city of Cianjur who were randomly selected and selected two classes as the experimental group that followed contextual learning and as a control group that followed ordinary learning. The data collection technique used is a test instrument. The statistical analysis used was the N-Gain score for the results of the mathematical problem-solving ability test. The results of the analysis regarding the improvement of problem solving skills with contextual learning are better about improving mathematical problem solving skills with ordinary learning. Contextual learning provides opportunities for students to be more active in learning and have a positive attitude towards mathematics subjects.
\end{abstract}

Keywords: Mathematical Problem Solving, Contextual Learning Approach.

\begin{abstract}
Abstrak
Penelitian ini bertujuan untuk menganalisis peningkatan kemampuan pemecahan masalah matematik melalui pendekatan pembelajaran kontekstual. Desain penelitian yang digunakan adalah desain dua kelompok dengan pretest-posttest. Populasi penelitian adalah seluruh siswa SMP Negeri di kota Cianjur. Sampel penelitian adalah siswa kelas VII SMP Negeri di kota Cianjur yang diambil secara acak dan terpilih dua kelas sebagai kelompok eksperimen yang mengikuti pendekatan pembelajaran kontekstual dan sebagai kelompok kontrol yang mengikuti pembelajaran biasa. Teknik pengumpulan data yang digunakan adalah instrumen tes. Analisis statistik yang digunakan adalah $\mathrm{N}$-Gain score untuk hasil tes kemampuan pemecahan masalah matematik. Hasil analisis menunjukkan bahwa peningkatan kemampuan pemecahan masalah dengan pendekatan pembelajaran kontekstual lebih baik daripada peningkatan kemampuan pemecahan masalah matematik dengan pembelajaran biasa. Pendekatan Pembelajaran kontekstual memberikan kesempatan kepada siswa untuk lebih aktif dalam pembelajaran dan memiliki sikap positif terhadap mata pelajaran matematika.
\end{abstract}

Kata Kunci: Pemecahan Masalah Matematik, Pendekatan Pembelajaran Kontekstual.

Matematika menurut Fitriani (Yuniarti, Sulasmini, Rahmadhani, Rohaeti, \& Fitriani, 2018) merupakan salah satu bagian yang penting dalam bidang ilmu pengetahuan. Jika dilihat dari pengklasifikasian bidang ilmu pengetahuan, pelajaran matematika termasuk ke dalam kelompok ilmuilmu eksakta (Wiliawanto, 2019), yang lebih banyak memerlukan pemahaman dari pada hafalan. Untuk dapat memahami suatu pokok bahasan dalam matematika, siswa harus mampu menguasai materi. Matematika perlu diberikan kepada semua siswa mulai dari sekolah dasar untuk membekali mereka dengan kemampuan berpikir logis, analitis, sistematis, kritis dan kreatif serta kemampuan bekerja sama.

Salah satu kemampuan esensial yang perlu dimiliki oleh siswa ialah kemampuan pemecahan masalah matematik. Kemampuan pemecahan masalah sangat terkait dengan kemampuan siswa dalam membaca dan memahami bahasa soal cerita, menyajikan dalam model matematika, merencanakan 
perhitungan dari model matematika, serta menyelesaikan perhitungan dari soal-soal yang tidak rutin (Timutius, 2018) yang merupakan proses penerimaan masalah sebagai tantangan (Maharani, 2018). Dan dapat dikaitkan dengan kehidupan sehari-hari (Nurhayati, 2019; Akbar, 2018; Al, 2018) serta mampu mengaplikasikannya (Chotimah, 2019; Bungsu, 2019). Pencapaian kemampuan pemecahan matematika memerlukan komunikasi matematika yang baik, dengan adanya interaksi yang seimbang antara siswa dengan siswa, atau pun siswa dengan guru (Anisa, 2014).

Pentingnya kemampuan pemecahan masalah matematik juga tercantum dalam tujuan umum pembelajaran matematik kurikulum 2013, yaitu :

a. Memahami konsep matematika, menjelaskan keterkaitan antar konsep dan mengaplikasikan konsep atau algoritma secara luwes, akurat, efisien, dan tepat dalam pemecahan masalah.

b. Menggunakan penalaran pada pola dan sifat, melakukan manipulasi matematika dalam membuat generalisasi, menyusun bukti atau menjelaskan gagasan dan pernyataan matematika.

c. Memecahkan masalah, yang meliputi kemampuan memahami masalah, merancang model matematika, menyelesaikan model dan menafsirkan hasil yang diperoleh.

d. Mengkomunikasikan gagasan dengan simbol, tabel,diagram,atau media lain untuk memperjelas keadaan atau masalah.

e. Memiliki sikap menghargai kegunaan matematika dalam kehidupan, rasa ingin tahu, perhatian dan minat dalam mempelajari matematika, serta sikap ulet dan percaya diri dalam pemecahan masalah.

Selain itu, menurut Sanjaya (Ritonga \& Surya, 2003) "Pemecahan Masalah (problem solving) dapat mengembangkan kemampuan siswa untuk berpikir kritis dan mengembangkan kemampuan mereka untuk menyesuaikan dengan pengetahuan yang baru. Pemecahan masalah mempunyai tujuan mendorong siswa lebih aktif untuk melakukan eksplorasi dalam menyelesaikan masalah (Bernard, 2018)

Namun, kenyataannya kemampuan pemecahan masalah matematik siswa Indonesia masih rendah, rendahnya kemampuan pemecahan masalah matematik siswa Indonesia ditinjau dari survey Program for International Students Assesment (PISA) tahun 2016 yang menunjukkan bahwa Indonesia menempati peringkat ke-64 dari 72 negara yang di survey dengan nilai 397 dari nilai yang ditetapkan PISA yaitu 500.

Rendahnya kemampuan pemecahan masalah matematik siswa juga diungkapkan oleh Biraftika (Bukhori, 2017) bahwa berdasarkan pengalaman menjadi pengajar di sekolah kebanyakan siswa tidak mampu menjawab soal-soal yang memuat pemecahan masalah yang tidak biasa. Rata-rata mereka belum mampu menyelesaikan soal dengan baik, mereka masih kebingungan dalam memahami masalah, belum mampu membuat rencana penyelesaian, tidak mampu membuat pendekatan matematikanya dan tidak memeriksa jawaban yang telah diselesaikan. Kebanyakan dari siswa cenderung menghindari soal yang membutuhkan kemampuan berpikir kritis yang baik dalam menghadapi masalah, mereka hanya menyukai soal yang rutin dan prosedural. 
Untuk meningkatkan kemampuan pemecahan masalah diperlukan suatu upaya salah satunya melalui pendekatan pembelajaran yang dapat merangsang siswa agar dapat belajar aktif, berorientasi pada proses, mengarahkan sendiri, mencari sendiri, dan reflektif sehingga siswa memiliki sikap mandiri dalam belajar serta mampu meningkatkan kemampuan pemecahan masalah. Oleh sebab itu, guru sebagai pendidik dituntut bisa menciptakan dan mengembangkan kemandirian anak didik serta mencipta konsep (Isnaeni, 2019). Peran guru bisa diwujudkan dengan mengajak anak didik belajar berbuat dan mengalami langsung serta keterlibatan secara aktif dalam lingkungan belajar.

Salah satu pembelajaran yang dapat meningkatkan kemampuan pemecahan masalah adalah pengajaran dan pembelajaran Kontekstual (CTL). Nurhadi (dalam Rusman, 2011:189) mengatakan bahwa "Pembelajaran Kontekstual (Contextual Teaching And Learning) adalah sebuah konsep pembelajaran yang membantu guru mengkaitkan antara materi yang diajarkannya dengan situasi dunia nyata dan mendorong pelajar membuat hubungan antara materi yang diajarkannya dengan penerapannya dalam kehidupan mereka sebagai anggota keluarga dan masyarakat."

Menurut Sanjaya (Suhartini, 2016) bahwa kontekstual ialah pendekatan yang memfokuskan pada proses siswa secara penuh agar dapat menemukan konsep yang dibahas dan menghubungkannya dengan kehidupan nyata sehingga mendorong siswa untuk menerapkannya dalam kegiatan mereka. Suherman (Suhartini, 2016) juga mengatakan bahwa pendekatan pembelajaran kontekstual ialah pembelajaran yang diawali dari mengambil contoh dari pengalaman yang dialami siswa lalu dikaitkan dengan konsep matematika dengan mengembangkan potensi kemampuan (Hidayat, 2019).

Dari pengertian di atas terlihat bahwa pendekatan kontekstual merupakan strategi pembelajaran yang menekankan kepada proses keterlibatan siswa secara penuh untuk dapat menemukan materi yang dipelajarinya dan menghubungkan dengan situasi kehidupan nyata sehingga mendorong siswa untuk dapat menerapkannya. Dalam pendekatan CTL siswa diharapkan dapat menguasai keterampilan berpikir dan memecahkan masalah matematik dengan baik. Pada penyajian masalah yang dekat dengan kehidupan nyata siswa, diharapkan siswa akan memiliki kemampuan terbiasa menghadapi masalah dalam kehidupan sehari-hari.

Berdasarkan latar belakang, maka peneliti tertarik untuk menelaah peningkatan kemampuan pemecahan masalah matematik tersebut, yang diharapkan semakin tinggi pengaruh pendekatan kontekstual maka akan berpotensi pula pada kemampuan matematik yang lain.

\section{METODE}

Metode penelitian yang digunakan dalam penelitian ini adalah kuasi eksperimen. Dengan populasinya adalah seluruh siswa SMP di Cianjur, dan diambil sampel dua buah kelas, kelas yang pertama (eksperimen) menggunakan pendekatan kontekstual dan kelas kedua (kontrol) menggunakan pembelajaran biasa. Adapun desain penelitian yang digunakan berbentuk desain kelompok pretespostes (Russeffendi: 2010) sebagai berikut. 


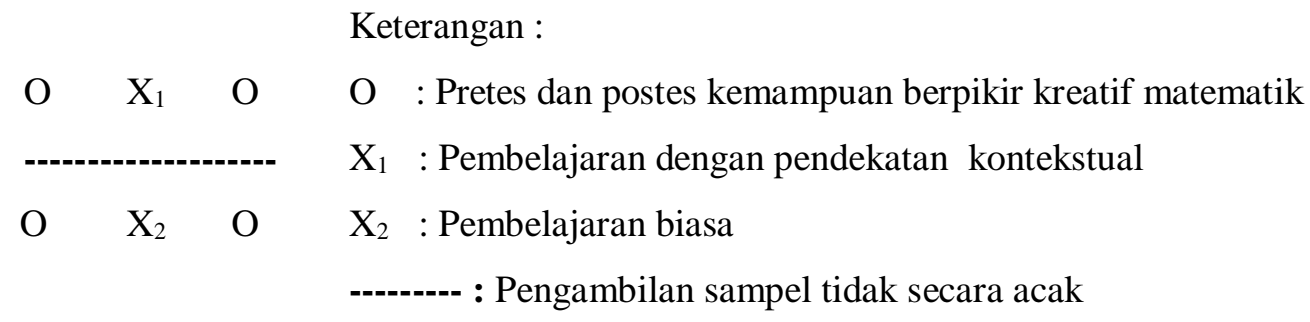

Instrument tes dalam penelitian ini berupa soal uraian sebanyak 5 butir soal. Pemberian soal uraian untuk melihat proses kreatif siswa, ketelitian dan sistematika penyusunan jawaban dari langkah-langkah penyelesaian soal. Tes awal diberikan untuk melihat sejauh mana kemampuan awal kedua kelas, sedangkan postes diberikan untuk mengetahui peningkatan kemampuan pemecahan masalah matematik siswa setelah dilakukan perlakuan yang berbeda. Data yang diperoleh dari hasil kemudian diuji menggunakan Software IBM SPSS Versi 22. Berikut salah satu contoh instrumen tes kemampuan pemecahan masalah matematik.

Layang-layang ABCD memiliki panjang BC sama dengan dua kali panjang AB ditambah $1 \mathrm{~cm}$. Besar sudut $A B C 90^{\circ}$. Jika luas layang-layang $42 \mathrm{~cm}^{2}$.

a. Apa yang kamu pahami dari permasalahan di atas?

b. Cukup, kurang atau berlebihankah data di atas jika ditanyakan keliling dari layang-layang tersebut? coba kamu periksa

\section{HASIL DAN PEMBAHASAN}

\section{Hasil}

Hipotesis dalam penelitian ini adalah "Peningkatan kemampuan pemecahan masalah matematik siswa menggunakan pendekatan kontekstual lebih baik daripada yang menggunakan pembelajaran biasa". Instrumen yang diujikan pada penelitian ini berupa soal-soal pemecahan masalah matematik dalam bentuk soal cerita yang mencakup materi bangun datar segitiga dan segiempat. Soal tersebut disusun berdasarkan kompetensi Inti dan kompetensi dasar dan indikator matematik SMP Kelas VII semester 2.

Data yang dianalisis pada penelitian ini berupa data N-gain kemampuan pemecahan masalah matematik dari kelas eksperimen dan kelas kontrol. Data N-gain merupakan data yang dipakai untuk menganalisis peningkatan kemampuan pemecahan masalah matematik sehingga terlihat perbedaan peningkatan pada kedua kelas. Data N-Gain diperoleh dari data pretes dan postes kelas eksperimen dan kelas kontrol. Berikut data pretes-postes kedua kelas. 
Peningkatan Kemampuan Memecahkan Masalah Matematik Siswa SMP Dengan Pendekatan Kontekstual, Elma Lusiana Arafani, Elin Herlina, Luvy Sylviana Zanthy

\section{Tabel 1}

Hasil Data Pretes-Postes kelas Eksperimen dan Kontrol

\begin{tabular}{|c|c|c|c|c|c|}
\hline \multirow{2}{*}{ NO } & \multirow{2}{*}{ Kode Siswa } & \multicolumn{2}{|c|}{ Kelas Eksperimen } & \multicolumn{2}{|c|}{ Kelas Kontrol } \\
\hline & & Pre-Test & Post-Test & Pre-Test & Post-Test \\
\hline 1 & S1 & 10 & 48 & 17 & 36 \\
\hline 2 & S2 & 5 & 44 & 6 & 35 \\
\hline 3 & S3 & 7 & 46 & 8 & 32 \\
\hline 4 & S4 & 7 & 42 & 7 & 34 \\
\hline 5 & S5 & 11 & 39 & 4 & 37 \\
\hline 6 & S6 & 12 & 39 & 8 & 30 \\
\hline 7 & S7 & 24 & 43 & 10 & 35 \\
\hline 8 & S8 & 13 & 46 & 5 & 38 \\
\hline 9 & S9 & 7 & 42 & 9 & 34 \\
\hline 10 & $\mathrm{~S} 10$ & 5 & 39 & 7 & 37 \\
\hline 11 & S11 & 7 & 46 & 17 & 33 \\
\hline 12 & $\mathrm{~S} 12$ & 8 & 39 & 7 & 42 \\
\hline 13 & S13 & 5 & 48 & 9 & 38 \\
\hline 14 & S14 & 15 & 38 & 8 & 32 \\
\hline 15 & S15 & 12 & 43 & 7 & 36 \\
\hline 16 & S16 & 11 & 44 & 7 & 41 \\
\hline 17 & S17 & 6 & 42 & 3 & 39 \\
\hline 18 & S18 & 7 & 41 & 2 & 36 \\
\hline 19 & S19 & 13 & 39 & 9 & 41 \\
\hline 20 & $\mathrm{~S} 20$ & 11 & 47 & 10 & 42 \\
\hline 21 & S21 & 13 & 43 & 8 & 39 \\
\hline 22 & S22 & 4 & 39 & 20 & 40 \\
\hline 23 & $\mathrm{~S} 23$ & 6 & 41 & 9 & 38 \\
\hline 24 & S24 & 8 & 31 & 7 & 39 \\
\hline 25 & S25 & 5 & 42 & 7 & 36 \\
\hline 26 & $\mathrm{~S} 26$ & 19 & 41 & 18 & 33 \\
\hline 27 & S27 & 15 & 39 & 17 & 40 \\
\hline 28 & S28 & 16 & 43 & 5 & 42 \\
\hline 29 & S29 & 14 & 40 & 15 & 29 \\
\hline 30 & $\mathrm{~S} 30$ & 11 & 39 & 17 & 43 \\
\hline 31 & S31 & 12 & 40 & 18 & 40 \\
\hline 32 & S32 & 5 & 37 & 15 & 39 \\
\hline 33 & S33 & 7 & 40 & 6 & 35 \\
\hline & ata-Rata & 10,0303 & 41,51515 & 9,75758 & 37 \\
\hline
\end{tabular}

Mengacu pada data di atas, terlihat bahwa hasil pretes nilai rata-rata kelas eksperimen yaitu 10,03 nilai tersebut tidak jauh berbeda dengan nilai rata-rata kelas kontrol yaitu 9,75, artinya tidak terdapat perbedaan kemampuan pemecahan masalah matematik siswa kelas eksperimen dengan kelas 
kontrol. Kemudian setelah dilakukan perlakuan yang berbeda antara kelas eksperimen yang pembelajarannya menggunakan pendekatan kontekstual dan kelas kontrol yang menggunakan pembelajaran biasa, diperoleh data postes yang menunjukkan bahwa kelas eksperimen memperoleh peningkatan, hal ini dapat dilihat dari nilai rata-rata postes kelas eksperimen yaitu 41,51 nilai ini lebih besar dari rata-rata kelas kontrol yaitu 37, sehingga dapat diduga pendekatan kontekstual dapat meningkatkan kemampuan pemecahan masalah matematik.

Kemudian data pretes-postes kelas eksperimen dan kontrol diolah untuk mencari nilai N-Gain yang kemudian dilanjutkan dengan menguji normalitas data N-Gain menggunakan uji statistik One Sample Kolmogorov-smirnov. Pengujian selanjutnya homogenitas varians skor N-Gain untuk melihat homogenitas atau kesamaan beberapa bagian sampel yaitu seragam tidaknya varians sampelsampel yang diambil dari populasi yang sama. Untuk menentukan peningkatan kemampuan pemecahan masalah matematik antara kelas eksperimen dan kelas kontrol digunakan uji perbedaan dua rata-rata menggunakan uji-t. Berikut disajikan data hasil pengolahan menggunakan aplikasi $I B M$ SPSS Versi 22.

\section{Tabel 2}

Hasil Data Uji Normalitas Data N-Gain Kemampuan Pemecahan Masalah Matematik

\begin{tabular}{|l|l|c|c|c|}
\hline \multirow{2}{*}{ Kelas } & \multicolumn{3}{|c|}{$\begin{array}{c}\text { Kolmogorov- } \\
\text { Smirnov }\end{array}$} \\
\cline { 3 - 5 } \multicolumn{2}{|c|}{} & $\begin{array}{c}\text { Stati } \\
\text { stic }\end{array}$ & df & Sig. \\
\hline $\begin{array}{l}\text { NGain_S } \\
\text { core }\end{array}$ & $\begin{array}{l}\text { Eksperi } \\
\text { men }\end{array}$ &, 096 & 33 & $.200^{*}$ \\
\cline { 2 - 5 } & Kontrol &, 137 & 33 & .117 \\
\hline
\end{tabular}

\section{Tabel 3}

Hasil Data Uji Homogenitas Skor N-Gain Kemampuan Pemecahan Masalah Matematik

\begin{tabular}{|c|c|c|c|}
\hline $\begin{array}{c}\text { Levene } \\
\text { Statistic }\end{array}$ & df1 & df2 & Sig. \\
\hline, 477 & 1 & 64 &, 492 \\
\hline
\end{tabular}

\section{Tabel 4}

Hasil Data Uji Perbedaan Dua Rata-Rata Skor N-GainKemampuan Pemecahan Masalah Matematik

\begin{tabular}{|c|c|c|c|c|c|c|}
\hline \multicolumn{2}{|c|}{} & F & Sig. & t & df & $\begin{array}{c}\text { Sig. (2- } \\
\text { tailed) }\end{array}$ \\
\hline $\begin{array}{c}\text { NGain_Sc } \\
\text { ore }\end{array}$ & $\begin{array}{c}\text { Equal variances } \\
\text { assumed }\end{array}$ &, 477 &, 492 & 4,887 & 64 &, 000 \\
\cline { 2 - 7 } & $\begin{array}{c}\text { Equal variances } \\
\text { not assumed }\end{array}$ & & 4,887 & 62,591 &, 000 \\
\hline
\end{tabular}




\section{Pembahasan}

Dari Tabel 4 di atas, dapat dilihat nilai signifikansi uji t pada skor N-Gain kemampuan pemecahan masalah matematik yaitu $0,000<0,05$ maka $\mathrm{H}_{0}$ ditolak. Hal ini disimpulkan terdapat perbedaan kemampuan pemecahan masalah matematik siswa yang diberi pembelajaran menggunakan pendekatan kontekstual dengan siswa yang diberi pembelajaran biasa.

Pembelajaran kontekstual bermula dari pembelajaran yang mengaitkan antara materi yang diajarkannya dengan situasi dunia nyata siswa dan mendorong siswa membuat hubungan antara pengetahuan yang dimiliki dengan penerapan dalam kehidupan mereka menurut Sanjaya (Ritonga \& Surya, 2003). Dengan konsep ini, hasil pembelajaran diharapkan lebih bermakna bagi siswa. Hal ini didukung oleh teori belajar Ausubel dalam hudujo 2005:73 (Ritonga \& Surya, 2003) mengatakan bahwa bahan pelajaran yang dipelajari haruslah "bermakna" (meaningful), artinya bahan pelajaran itu cocok dengan kemampuan siswa dan harus relevan dengan struktur kognitif yang dimiliki siswa. Dengan perkataan lain, pelajaran baru haruslah dikaitkan dengan konsep-konsep yang sudah ada sedemikian hingga konsep-konsep benar-benar terserap. Peroses pembelajaraan berlangsung secara alamiah dalam bentuk kegiatan siswa bekerja dan mengalami, dan strategi pembelajaran lebih dipentingkan daripada hasil. Dalam kelas kontekstual, tugas guru adalah membantu siswa mencapai tujuannya. Maksudnya guru lebih banyak berurusan dengan strategi dari pada memberi informasi.tugas guru mengelola kelas sebagai sebuah tim yang bekerja bersama untuk menemukan sesuatu yang baru bagi siswa. Sesuatu yang baru (pengetahuan dan keterampialn) datang dari menemukan sendiri bukan dari apa kata guru. Berdasarkan hasil analisis penelitian dan kajian teori di atas, maka terbukti benar bahwa pembelajaran kontekstual tepat digunakan untuk meningkatkan kemampuan pemecahan masalah matematika siswa.

Dari pengolahan data diduga pendekatan pembelajaran kontekstual memberikan peningkatan yang positif, baik mengenai hasil belajarnya maupun respon/sikap siswa terhadap pembelajarannya. Siswa terlihat lebih aktif pada saat kegiatan kelompok dalam memecahkan masalah. Hal ini dikarenakan pembelajaran matematika menggunakan pendekatan kontekstual, siswa diberi kesempatan seluas-luasnya untuk mengeksplor pengetahuan yang mereka miliki untuk membangun konsep matematika yang sedang dipelajari. Dari kegiatan tadi siswa akan mudah dalam mengingat materi,karena konsep matematika tersebut mereka yang menemukan sendiri. Setelah itu siswa menyimpulkan dengan menggunakan rumus ataupun konsep matematika untuk menyelesaikan permasalahan matematika yang mereka hadapi sesuai kaidah yang berlaku.

Hal ini sejalan dengan penelitian yang dilakukan oleh (Zannah, Mulyasari, \& Fitriani, 2016) yang berjudul "Pendekatan Contextual Teaching And Learning Untuk Meningkatkan Kemampuan Pemecahan Masalah Matematis Siswa" dan penelitian (Permata, 2016) dengan judul "Upaya Meningkatkan Kemampuan Pemecahan Masalah Matematika Melalui Pendekatan Contextual Teaching And Learning ( CTL ) Siswa Kelas VIIID SMP Negeri 1 Mlati” yang menyimpulkan bahwa pendekatan kontekstual dapat meningkatkan kemampuan pemecahan masalah matematik siswa. 


\section{KESIMPULAN}

Berdasarkan hasil penelitian kemampuan memecahkan masalah matematik siswa SMP di Kota Cianjur pada materi bangun datar dapat disimpulkan secara umum kemampuan pemecahan masalah matematik siswa yang menggunakan pendekatan kontekstual lebih baik daripada pembelajaran biasa. Adapun saran peneliti untuk peneliti yang akan menggunakan pendekatan kontekstual dalam penelitiannya, disarankan untuk menerapkannya pada pokok bahasan lain yang lebih kompleks, selain itu juga disarankan agar pendekatan kontekstual digunakan untuk mengukur peningkatan pada kemampuan matematik lainnya selain kemampuan pemecahan masalah matematik yang sudah diteliti pasa penelitian ini. Selain itu juga diharapkan agar pendekatan kontekstual dapat digunakan untuk jenjang SMA atau SMK, mengingat pada kesempatan kali ini penelitian menggunakan pendekatan kontekstual diberikan kepada sampel tingkat SMP.

\section{DAFTAR PUSTAKA}

Akbar, P., Hamid, A., Bernard, M., \& Sugandi, A. I. (2018). Analisis kemampuan pemecahan masalah dan disposisi matematik siswa kelas xi sma putra juang dalam materi peluang. Jurnal Cendekia: Jurnal Pendidikan Matematika, 2(1), 144-153.

Anisa, W. N. (2014). Peningkatan Kemampuan Pemecahan Masalah Dan Komunikasi Matematik Melalui Pembelajaran Pendidikan Matematika Realistik Untuk Siswa SMP Negeri Di Kabupaten Garut. Jurnal Pendidikan Dan Keguruan, 1(1).

Al Ayyubi, I. I., Nudin, E., \& Bernard, M. (2018). Pengaruh Pembelajaran Berbasis Masalah terhadap Kemampuan Pemecahan Masalah Matematis Siswa SMA.JPMI (Jurnal Pembelajaran Matematika Inovatif), 1(3), 355-360.

Bernard, M., Nurmala, N., Mariam, S., \& Rustyani, N. (2018). Analisis Kemampuan Pemecahan Masalah Matematis Siswa SMP Kelas IX Pada Materi Bangun Datar. SJME (Supremum Journal of Mathematics Education), 2(2), 77-83.

Bukhori. Dkk. (2017). Peningkatan Kemampuan Pemecahan Masalah dan Kemandirian Belajar Siswa Melalui Pendekatan Contextual Teaching and Learning di Sekolah Menengah Pertama. Medan: Jurnal Tabulara.

Bungsu, T. K., Vilardi, M., Akbar, P., \& Bernard, M. (2019). Pengaruh Kemandirian Belajar Terhadap Hasil Belajar Matematika Di Smkn 1 Cihampelas. Journal on Education, 1(2), 382389.

Chotimah, S., Ramdhani, F. A., Bernard, M., \& Akbar, P. (2019). Pengaruh Pendekatan ModelEliciting Activities Terhadap Kemampuan Berpikir Kritis Matematik Siswa Smp Negeri Di Kota Cimahi. Journal on Education, 1(2), 68-77.

Hendriana, H, Rohaeti, E,E. Sumarmo,U.(2018). Hard Skills dan Soft Skills Matematik Siswa. Bandung. Refrika Aditama 
Peningkatan Kemampuan Memecahkan Masalah Matematik Siswa SMP Dengan Pendekatan Kontekstual, Elma Lusiana Arafani, Elin Herlina, Luvy Sylviana Zanthy

Hidayat, F., Akbar, P., \& Bernard, M. (2019). Analisis Kemampuan Berfikir Kritis Matematik Serta Kemandiriaan Belajar Siswa Smp Terhadap Materi Spldv. Journal on Education, 1(2), 515-523.

Isnaeni, S., Ansori, A., Akbar, P., \& Bernard, M. (2019). ANALISIS KEMAMPUAN KONEKSI MATEMATIS SISWA SMP PADA MATERI PERSAMAAN DAN PERTIDAKSAMAAN LINEAR SATU VARIABEL. Journal on Education, 1(2), 309-316.

Mahardiningrum, Sri, A, Ratu, N. (2018). Profil Pemecahan Masalah Matematik Siswa SMP Pangudi Luhur Salatiga Ditintau Dari Berfikir Kritis. Sidorejo, Mosharafa.

Maharani, S., \& Bernard, M. (2018). Analisis Hubungan Resiliensi Matematik Terhadap Kemampuan Pemecahan Masalah Siswa Pada Materi Lingkaran. JPMI (Jurnal Pembelajaran Matematika Inovatif), 1(5), 819-826.

Nurhayati, N., \& Bernard, M. (2019). Analisis Kesulitan Siswa Dalam Pemecahan Masalah Matematik Siswa Kelas X SMK Bina Insan Bangsa Pada Materi Persamaan Dan Pertidaksamaan. Journal on Education, 1(2), 497-502.

Permata, R. D. (2016). Upaya meningkatkan kemampuan pemecahan masalah matematika melalui pendekatan contextual teaching and learning ( CTL ) siswa kelas viiid smp negeri 1 melati.

Ritonga, M. Z. F., \& Surya, E. (2003). Meningkatkan Kemampuan Pemecahan Masalah Matematika Siswa Dengan Menggunakan Model Pembelajaran Kontekstual. (December)

Rusman., (2011), Model-Model Pembelajaran, PT Raja Grafindo Persada, Jakarta.

Ruseffendi, E.T. (2010). Dasar-Dasar Penelitian Pendidikan \& Bidang Non Eksakta Lainnya. Bandung: Tarsito.

Suhartini, I.Syahputra, E.Surya, E. (2016). Pengaruh Pembelajaran Kontekstual Terhadap Kemampuan Pemecahan Masalah Matematik dan Kemandirian Belajar Siswa di MTs Miftahussalam Medan. Medan. Paradikma

Timutius, F., Apriliani, N. R., \& Bernard, M. (2018). Analisis Kesalahan Siswa Kelas IX-G di SMP Negeri 3 Cimahi dalam Menyelesaikan Soal Pemecahan Masalah Matematik pada Materi Lingkaran. JPMI (Jurnal Pembelajaran Matematika Inovatif), 1(3), 305-312.

Wiliawanto, W., Bernard, M., Akbar, P., \& Sugandi, A. I. (2019). Penerapan Strategi Pembelajaran Aktif Question Student Have Untuk Meningkatkan Kemampuan Berpikir Kritis Matematik Siswa SMK. Jurnal Cendekia: Jurnal Pendidikan Matematika,3(1), 139-148.

Yuniarti, N., Sulasmini, L., Rahmadhani, E., Rohaeti, E. E., \& Fitriani, N. (2018). Dengan Self Esteem Siswa Smp Melalui Pendekatan Contextual Teaching And Learning. 2(1), 62-72.

Zannah, C. R., Mulyasari, E., \& Fitriani, A. D. (2016). Pendekatan Contextual Teaching and Learning Untuk Meningkatkan Kemampuan Pemecahan Masalah Matematis Dan Motivasi Belajar Siswa. 1(1), 411-420. https://doi.org/10.17509/jpi.v1i1.30 